\title{
SKILL MAPPING, TALENT POOL MANAGEMENT AND ORGANISATIONAL DEVELOPMENT: EVIDENCE FROM PROFESSIONAL BODIES IN NIGERIA
}

\author{
Matthew Adekunle ABIORO ${ }^{1}$, Jayeola OLABISI ${ }^{2}$, \\ Isaac Oladepo ONIGBINDE ${ }^{3}$, Adedolapo Mercy ADEDEJI ${ }^{4}$ \\ ${ }^{1,2,4}$ Federal University of Agriculture, Abeokuta, Ogun State, Nigeria \\ ${ }^{3}$ McPherson University, Seriki Sotayo, Abeokuta, Ogun State, Nigeria
}

Corresponding author's e-mail: olabisij@funaab.edu.ng

\begin{abstract}
The study examined the influence of skill mapping and talent pool management on organisational development in Nigeria. The study adopted a survey research and the study population comprised three thousand (3000) active members of Chartered Institute of Personnel Management (CIPM) in Nigeria as at 2019. A research instrument, well structured, titled "Skill mapping, talent pool management and organisational development" was used to collect data from a sample size of 353 members randomly selected from the population. Descriptive and inferential statistics were adopted to analyse the formulated hypotheses. The result of the study showed a positive effect of employee engagement on organisational development $\left(R^{2}=0.664, P=0.000\right)$; and a significant effect of succession planning on organisational development $\left(R^{2}=0.781, P=0.000\right)$. There was also a significant effect of job rotation on organisational development $\left(R^{2}=0.392, P=0.000\right)$. The study concluded that skill mapping and talent pool management (in terms of properly matching tasks with personnel) played a significant role in the development of an organisation. Therefore, the study recommended that human resource managers at every organisation should strive to keenly match employee with tasks where they were more skilful and talented, as failure to do this, might result in employees' inefficiency and turnover.
\end{abstract}

Keywords: Employee engagement; Job rotation; Skill mapping; Succession planning; Talent pool management.

JEL Classification: $\mathrm{H} 2 ; \mathrm{H} 23 ; 25 ; 26$

\section{INTRODUCTION}

In times like this where technologies are evolving on a continual basis, only business that pays keen attention to skills and talents of its workforce enjoys business success. There is no doubt the fact that people differ from one to another and the way and manner of getting things done through people are also different. At present time, many organisations engage employees from different cultural background with various skills and talents. While some employees are aware of the talents deployed in them, the study revealed that many of them do not know their skills (Aradhna, 2017). Hence, the prominence of skill mapping and talent pool 
management in this age has become a contentious issue among business owners and professionals.

According to Nair (2012), skill mapping has been found to be one of the most crucial strategies of talent management practices for effective performance in terms of staff retention, development, employee engagement and succession planning. It has also to do with the process of analysing and studying the various skills of individual. It is a comprehensive way of knowing the skill levels and potentials of people concerned. It equally assists to identify areas where there is deficiency in skills and where appropriate training is required for improvement. Skill mapping, thus, is fast becoming important, for any organisation aiming at competing favourably in the dynamic business environment (Nair, 2012).

Talent pool management, on the other hand, has different interpretations to different people. To some, it is about how individual or talented employees can be managed. As explained by Masri and Suliman (2019), talent management is concerned with the different processes and activities of identifying key positions that contribute to the organisation's sustainable competitive advantage. It equally implies identifying an individual's intrinsic competence, characteristics, and qualities with the aim of providing such individual with a matching job that suits almost what he/she is best at (Mensah, 2015). The development of a talent pool of high-potential and high-performing workforce is to fill various positions in the organisation, and the development of differentiated human resource architecture to facilitate filling these positions with competent workforce, and ensure continued commitment to critical surviving factors of an organisation (Mensah, Bawole \& Wedchayanon, 2016).

Skill mapping and talent pool management are becoming more popular expressions in today's corporate world. While organisations have consistently trusted its relevance and significance of having right individuals at the right place, at the right time, doing the right task, they have also started coming into the reality of how it equally affects the effectiveness vis-a-vis the development of their organisation (Smithesh and Shameem, 2018).

Management scholars and professionals have argued over the years that management efficiency and effectiveness are achievable when there is a thorough understanding of employees' personalities, behavioural styles, and their work environment (Dehkordy, 2014). However, previous research about the present study has discovered that organisations experienced misfortunes and ineffectiveness (loses) possibly because of incorrect allocation of work to the staff (Genty, 2019). Consequently, understanding the abilities, intentions, concealed possibilities, qualities of the people working at the organisation together with matching them with a similar task can be hectic considering the fact that every job has its own demands and specification (Chandan, 2015). Hence, organisations in every sector of the economy all over the world have joined the quest for competencies.

It is therefore imperative for various organisations to coordinate competences and talents of the workers with the prerequisites of job requirement before allotting the task to them. The question of whether skill mapping and talent pool management improve or worsen organisational development is still worthy of advancing 
exploration and this is one of the focal points for the present research. It is against this back drop that this study attempts to fill this gap by studying the situation of the Nigerian professional bodies using Chartered Institute of Personnel Management (CIPM) as the study area. The specific objectives of this study are as follows:

- to examine the effect of employees' engagement on organisational development;

- to assess the implication of succession planning in organisational development;

- to evaluate the effect of job rotation on organisational development.

The following section of the paper reviews the conceptual, theoretical and empirical studies, while Section 3 describes methods and procedures. Section 4 discusses the results of the study and Section 5 presents findings of the study. The last section concludes the study and makes policy recommendations.

\section{LITERATURE REVIEW}

\subsection{Conceptual Review}

\subsubsection{Concept of Skill Mapping}

Every individual is expected to be the best at one thing or the other as nobody lays demand on an individual to be the best at everything. This illustration is exactly what resulted in skill mapping. Skill mapping is an act of taking a close watch on individual skills, and appropriately match them to suitable job or task, otherwise this may cause frustration in the organisation (Deepti, Sachin \& Kalpana, 2017). Apparently, since an employee is the best at a task, he should be fixed with such a task and not any other; this in the long run leads to productivity and maximum result. The problem mostly is that managers tend to misrepresent the concept of effectiveness and efficiency by thinking once they can get an employee to work on three (3) to four (4) jobs, whether they are the best at jobs or not, in as much there is a result, then they are efficient. Efficiency and effectiveness are not characterised by the number of jobs, but how well and productive an individual is in that specific job assigned to them (Celia \& Karthick, 2010). Therefore, the process of mapping an individual against the ideal set is one factor where a great deal of sensitivity is required by the organisation.

\subsubsection{Concept of Talent Pool Management}

In the present day, there is a shift from the casual human resource process to talent management where emphasis is on management of skills, integration of systems, productivity level, succession planning, and effective leadership styles (Genty, 2019). In a sector where all that employees have to offer is skills and knowledge, i.e., a service-based sector, the only way to be well positioned in the competitive market is the extent of qualitative skills and knowledge (Gallardo, 2013). The main reason for talent management is the proper alignment of task with intrinsic traits and personality (Jayaraman, Parvaiz \& Ahmad, 2018). It is very 
possible that the skills and talents required in the past are quite different, if not entirely different from the one needed. There is a whole lot of vastness in the business world that may not require the old skills. Business is tagged relic if they cannot flow in this reality. In view of this, managers should pay more attention to recruitment process. Aligning jobs and skills is demanding, no doubt, but it is also imperative that right talents are allocated to right tasks (Nair, 2012).

\subsection{Component of Skill Mapping and Talent Pool Management Employee Engagement}

Engaged staff are individuals who have passion and enthusiasm about their jobs. It is also necessary to ensure the right work conditions and atmosphere at the organisation for all members in order to motivate them to give their best towards the development of the business (Bakker \& Xu, 2011). The focus of employee engagement is to ensure that an employee has a sense of belonging to an organisation. Trust, integrity, commitment and communication are key components of employee engagement. Adopting the strategy of employee engagement brings about an increase in productivity of the workforce, and the chance of business success is high. The individual and organisation work together in order to achieve industrial harmony (Deepti, Sachin \& Kalpana, 2017). These propositions assist in the formulation of the first null hypothesis:

Ho: Employee engagement has no significant effect on organisation development.

\section{Succession Planning}

For any business to continue to be in existence over a period of time there is a need for such an organisation to key into the succession planning programme. The concept has to do with searching and developing an individual in the system that can fill a vacant position in an organisation, which occurs as a result of retrenchment, resignation, retirement, or death. The strategy behind succession planning is to ensure that there is no vacuum in the operations of the business in case of exit of the most important employee within the organisation. The concept which is also known as 'replacement planning' brings about leadership skills and prepares the employees to take on higher responsibility at any point in time at the organisation (Seniwoliba, 2015). These observations lead to the second null hypothesis:

Ho: There is no significant effect of succession planning on organisational development.

\section{Job Rotation}

Basically, the rationale behind this concept is to expose employees to areas in another department at the organisation where they are deficient. The concept, which is also known as 'job shadowing', is a management approach aimed at testing the competencies, abilities, knowledge and skills of all the employees so as to place such an individual at the right place, at the right time, doing the right task in order for the organisation to achieve its stated goals and objectives. The strategy is to 
ensure that employees are rotated from one department to another within the system on a regular basis so as to give them all the necessary exposure required to sustain the business. The key component of job rotation is that the boredom of doing the same work over and over is reduced, and it equally gives a wider experience to employees by providing more adequate insight and reducing monotony of job (Soundara \& Ananda, 2016). The observation also leads to the third null hypothesis:

Ho: Job rotation has no significant effect on organisational development.

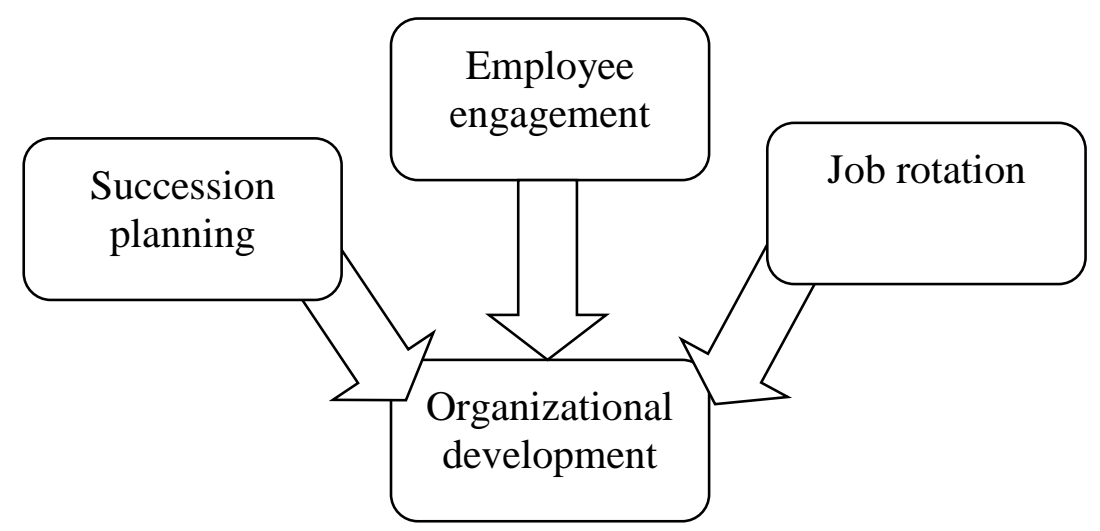

Fig. 1. Researcher conceptual model, 2019.

\subsection{Theoretical Review}

The resource-based view (RBV) theory was adopted for this study-reason being that it provided an insight as regard the role of human resources in terms of knowledge, skills and abilities (KSA) in an organisation in gaining competitive advantage (Sparrow \& Makram, 2015). To provide sustained competitive advantage, a resource must have four qualities and RBV classifies them as essential resources. These are: valuable, rare, inimitable, and non-substitutable (VRIN). However, a sustainable competitive advantage can be achieved through management of talent practice which includes managing, engaging, motivating, developing, positioning, and talent retention (Mattone \& Xavier, 2013). Hence, the resource-based view theory was planned to consider the rare and inimitable human resource management of an organisation.

Furthermore, resource-based view theory is of the view that those specific competencies within an organisation may be enhanced to gain sustainable competitive advantage and development of the business by adapting human resource system (Tetik, 2016). Mapping of skills and competencies has been connected to the efforts of companies to improve their workforce in order to increase innovation, development and effectiveness (Draganidis and Mentzas, 2006; Tatoglu, Glaister \& Demirbag, 2016). Therefore, in the utilisation of value, rareness, inimitability and substitutability concepts, Dunford, Snell \& Wright (2001) suggest that human capital pool must have both high levels of skill and willingness in terms of motivation to exhibit productive behaviour. 


\subsection{Empirical Review}

A number of empirical studies have been conducted on the subject matter of skill mapping and talent pool management. Quite a number of studies found out that a competency-based selection method is healthy and should be adopted to achieve organisational development. Employees are evaluated on the competencies needed to demonstrate when employed into the organisation (Gilbert, 2012).

Thomas, Carbery, and Rock, (2011) explored the concept of talent development, defined its scope and identified issues involved in formulating talent development strategies at an organisation. The authors' findings suggested that key success factors usually identified in the literature in top level commitment and strategic integration were insufficient and overrated aspects. Of significantly more importance are "non-issues" in the formulation of diversity strategies, organisational alignment of relevant organisational players, strategic coherence and organisational culture. The implications of the research suggest that talent management activities targeted at fostering ethnic diversity in talent development require specific awareness at the outset of cultural and organisational conditions and processes underpinning standard practices of talent and career development.

Research by Sheokand and Verma (2015) opine that in the $21^{\text {st }}$ century the study of skill mapping and talent pool management, even though is debatable based on other studies conducted in the past, leads to a high performing organisation. Oladapo (2014) argues that an organisation tends to increase in terms of profit when it puts in place a strategy to retain its top/key talent and not only that, there will be development when the business is able to effectively manage its talent by adopting the best talent management practices in the organisation.

Kaur and Kumar (2013) examined the impact of competency mapping on filling the required skills at an organisation. The study measured the competency of three different levels of management with the help of a well-structured questionnaire. It was revealed that competency mapping would help an organisation to fill the gap in the skill needed in order to ensure organisational effectiveness and efficiency.

Krishnaveni (2013) assessed the competency of the employees at the Research Centre, Madurai, India. It was revealed that competency mapping played a significant role towards the development of both the employee and organisation at large. It is, therefore, necessary for any business that desires to have a competitive edge on others in the same line of trade to maximise the potentials of its formidable workforce.

Maura (2011) also studied the relationship between talent management and multinational corporation (MNC) performance. The findings from the research imply that investment in talent and skills development has a negative influence on the performance of the organisation. In order to enhance organisational effectiveness, the environment should be created in such a way that it will encourage employees to increase their skills because higher employee skills and talents lead to higher organisational development and effectiveness.

This study intends to further expand the frontiers of knowledge by investigating the effect of skill mapping and talent pool management on organisational development among members of professional bodies in Nigeria. 


\section{METHODS AND PROCEDURES}

This study adopted a survey research design, where primary data were collected through a structured questionnaire to investigate the effect of skill mapping and talent pool management on organisational development among the Nigerian professional institutions. The study targeted at a total working population of three thousand (3000) active members of Chartered Institute of Personnel Management (CIPM) in Nigeria. By adopting the figure as the study population, a simple random sample method was used through Yamane's (1967) formula as given below:

$$
n=\frac{N}{1=N(e)^{2}},
$$

Where the sample size, $N$ is the population size (active members of CIPM) and $e$ is the sampling error (0.05). From the expression above, the sample size is obtained as follows:

$$
n=\frac{3000}{\left(1+3000(0.05)^{2}\right)}=352.9
$$

Hence, a total sample size of three and fifty-three (353) members were chosen from the entire working population. The researchers administered a total of 353 questionnaires in order to reduce a sampling error, minimise the case of nonresponse bias and non-return of questionnaire. Out of three hundred and fifty-three (353) questionnaires distributed, 280 were properly filled, returned and analysed.

The questions were separated into two sections: section A focusing on demographic report of respondents, while section B dealing with questions relating to the subject matter of the research as demonstrated in Table 2 below. Likert type interval rating scale which allows respondents to grade their opinion on scale of 1 to 5 was used to elicit appropriate responses, where $5=$ Strongly agree, $4=$ Agree, $3=$ Undecided, $2=$ Disagree, and $1=$ Strongly disagree. Both descriptive and inferential statistics were used to analyse the data generated. A descriptive tool was used to analyse the demographical characteristics of the respondents, while regression analysis techniques were employed to test the formulated hypotheses.

\section{RESULTS AND FINDINGS}

This section outlines the presentation, analysis and interpretation of data collected from the respondents through the questionnaire. The data generated from the personal profile of the respondents were used to arrive at the descriptive analysis.

Table 1 shows the total number of three hundred and fifty questionnaires administered to the respondents. Two hundred and eighty (280) questionnaires representing $80 \%$ were properly filled and returned and seventy-three (73) questionnaires representing $20 \%$ were not returned. This means that the number of returned questionnaires is good enough to make valid conclusions. 
Table 1. Analysis of Response Rate

\begin{tabular}{|l|c|c|c|}
\hline \multicolumn{1}{|c|}{ Questionnaire } & $\begin{array}{c}\text { Chartered Institute of Personnel } \\
\text { Management (CIPM) }\end{array}$ & Total & Percentage, \% \\
\hline Returned & 280 & $\mathbf{2 8 0}$ & 80.0 \\
\hline Not returned & 73 & $\mathbf{7 3}$ & 20.0 \\
\hline Total distributed & $\mathbf{3 5 3}$ & $\mathbf{3 5 3}$ & 100 \\
\hline
\end{tabular}

Source: Researchers' computation, 2019.

Table 2. Descriptive Statistics of Skill Mapping, Talent Pool Management and Organisational Development

\begin{tabular}{|c|c|c|c|}
\hline Items & $N$ & Mean & $\begin{array}{l}\text { Std. } \\
\text { Deviation }\end{array}$ \\
\hline EMPLOYEE ENGAGEMENT & & & \\
\hline $\begin{array}{l}\text { Employee engagement involves putting the right people in the } \\
\text { right place, doing the right work at the right time. }\end{array}$ & 280 & 2.34 & 1.49 \\
\hline $\begin{array}{l}\text { Ensuring proper utilization of talents and potentials at an } \\
\text { organisation is imperative. }\end{array}$ & 280 & 4.85 & 1.76 \\
\hline $\begin{array}{l}\text { Employee engagement is not just based on organisational goals; } \\
\text { it allows for flexibility to balance work with other activities that }\end{array}$ & 280 & 3.28 & 1.33 \\
\hline $\begin{array}{l}\text { are important. } \\
\text { An engaged employee is said to be a performing organisation. }\end{array}$ & 280 & 3.90 & 1.59 \\
\hline $\begin{array}{l}\text { Positive attitudes and behaviours are a signal of employee } \\
\text { engagement at an organisation. }\end{array}$ & 280 & 3.72 & 1.88 \\
\hline $\begin{array}{l}\text { Involving employees in decision making is a good practice that } \\
\text { an organisation should embrace. }\end{array}$ & 280 & 4.60 & 0.37 \\
\hline \multicolumn{4}{|l|}{$\begin{array}{l}\text { SUCCESSION PLANNING } \\
\end{array}$} \\
\hline $\begin{array}{l}\text { Attaching subordinates to superiors for proper coaching and } \\
\text { development is an ideal practice in any organisation. }\end{array}$ & 280 & 3.48 & 1.61 \\
\hline $\begin{array}{l}\text { A good and adequate succession plan can help identify the next } \\
\text { generation of leaders, prevent high cost of hiring and increase } \\
\text { retention. }\end{array}$ & 280 & 3.76 & 1.45 \\
\hline $\begin{array}{l}\text { Making provisions for succession planning may reduce the harm } \\
\text { caused by an unanticipated succession event. }\end{array}$ & 280 & 2.17 & 1.60 \\
\hline $\begin{array}{l}\text { Deliberate staff development at different intervals allows for } \\
\text { better organisational result. }\end{array}$ & 280 & 3.52 & 1.49 \\
\hline $\begin{array}{l}\text { Poor leadership in an organisation can be as a result of lack of } \\
\text { good succession planning process. }\end{array}$ & 280 & 3.91 & 1.36 \\
\hline $\begin{array}{l}\text { Good succession planning management brings about } \\
\text { organisational development. }\end{array}$ & 280 & 4.19 & 1.92 \\
\hline \multicolumn{4}{|l|}{ JOB ROTATION } \\
\hline $\begin{array}{l}\text { Moving staff from one department to another helps in employee } \\
\text { development. }\end{array}$ & 280 & 3.00 & 1.29 \\
\hline $\begin{array}{l}\text { Learning about different departments can help employees gain } \\
\text { confidence in the organisation. }\end{array}$ & 280 & 3.42 & 1.88 \\
\hline $\begin{array}{l}\text { Ability to have an experience of what other units look like } \\
\text { negates the boredom of a particular job position. }\end{array}$ & 280 & 3.60 & 1.37 \\
\hline $\begin{array}{l}\text { At an organisation, job rotation is needed more than employee } \\
\text { training. }\end{array}$ & 280 & 3.95 & 1.40 \\
\hline $\begin{array}{l}\text { Job rotation is a good platform to discuss new talent within an } \\
\text { organisation. }\end{array}$ & 280 & 2.63 & 1.94 \\
\hline Job rotation can lead to competition among team members. & 280 & 4.12 & 1.55 \\
\hline
\end{tabular}




\begin{tabular}{|l|c|c|c|}
\hline \multicolumn{1}{|c|}{ ORGANISATIONAL DEVELOPMENT } & \multicolumn{2}{|c|}{} \\
\hline $\begin{array}{l}\text { Skill mapping usually help managers be more productive. } \\
\text { Proper management of talents and abilities disallows frustration } \\
\text { at an organisation. }\end{array}$ & 280 & 3.48 & 1.26 \\
$\begin{array}{l}\text { Focus on education and growth through training and coaching } \\
\text { gives an organisation an edge over competitors. }\end{array}$ & 280 & 3.91 & 1.00 \\
$\begin{array}{l}\text { Involvement of employees in the decision-making process paints } \\
\text { a clear and broad picture of the organisational goals and } \\
\text { objectives. }\end{array}$ & 280 & 3.50 & 1.77 \\
$\begin{array}{l}\text { Willingness of employees in the engagement of work activities } \\
\text { reduces stress and tension at an organisation. }\end{array}$ & 280 & 4.26 & 1.62 \\
$\begin{array}{l}\text { Proper allocation of tasks to employees reduces wastage at an } \\
\text { organisation. }\end{array}$ & 280 & 3.48 & 1.43 \\
\hline AVERAGE & & $\mathbf{3 . 5 9}$ & \\
\hline
\end{tabular}

Source: Researchers' computation, 2019.

Table 2 revealed the descriptive statistics of skill mapping, talent pool management variables and organisational development with the mean and standard deviation values of the factor analysis. However, on the statement of evaluation, the average mean value is (3.59).

\section{Test of Hypotheses}

The tables below revealed the result of the regression analysis carried out to investigate the effect of skill mapping and talent pool management on organisational development.

\section{Hypothesis One:}

$\mathbf{H}_{0}$ : Employee engagement has no significant effect on organisation development.

Table 3. Regression results

$$
\left(R=0.664 ; R^{2}=0.441 ; \text { Adjusted } R^{2}=0.439 ; F \text { Stat }=219.238\right)
$$

\begin{tabular}{|c|c|c|c|c|c|}
\hline \multirow{2}{*}{ Model } & \multicolumn{2}{|l|}{ Unstandardised Coefficients } & $\begin{array}{c}\text { Standardised } \\
\text { Coefficients }\end{array}$ & \multirow{2}{*}{$\boldsymbol{T}$} & \multirow{2}{*}{ Sig. } \\
\cline { 2 - 4 } & $\boldsymbol{B}$ & Std. Error & Beta & & \\
\hline Constant & 2.518 & 0.433 & & 5.822 & 0.000 \\
\hline Employee Engagement & 0.758 & 0.051 & 0.664 & 14.807 & 0.000 \\
\hline
\end{tabular}

Dependent Variable: Organisational Development

\section{Interpretation}

Hypothesis One has a beta coefficient of 0.664 (66.4\%), which shows a positive influence of employee engagement on organisational development, $R^{2}$ of 0.441 (44.1\%), which implies that employee engagement can account for $44.1 \%$ of variation in organisational development. $P<0.05$, this connotes that the result is significant. The result of Hypothesis One shows that employee engagement has a significant effect on organisational development. 


\section{Hypothesis Two:}

$\mathbf{H}_{0}$ : There is no significant effect of succession planning on organisational development.

Table 4. Regression results

$$
\left(R=0.781 ; R^{2}=0.441 ; \text { Adjusted } R^{2}=0.194 ; F \text { Stat }=67.238\right)
$$

\begin{tabular}{|l|c|c|c|c|c|}
\hline \multirow{2}{*}{ Model } & \multicolumn{2}{|c|}{ Unstandardised Coefficients } & $\begin{array}{c}\text { Standardised } \\
\text { Coefficients }\end{array}$ & \multirow{T}{*}{ Sig. } \\
\cline { 2 - 4 } & $\boldsymbol{B}$ & Std. Error & Beta & & \\
\hline Constant & 3.473 & 0.461 & & 10.276 & 0.000 \\
\hline $\begin{array}{l}\text { Succession } \\
\text { Planning }\end{array}$ & 0.382 & 0.055 & 0.526 & 8.329 & 0.000 \\
\hline
\end{tabular}

Dependent Variable: Organisational Development

\section{Interpretation}

Hypothesis Two revealed a beta coefficient of 0.526 (52.6\%); it explains that succession planning has a positive impact on organisational development, with $R^{2}$ value of $0.781(78.1 \%$ ), which implies that succession planning contributes to $78.1 \%$ of the variation that occurs in organisational development; while a significant level is less than 0.05 . This indicates that the result is significant. The overall result shows that succession planning has a significant effect on organisational development.

\section{Hypothesis Three:}

Ho: Job rotation has no significant effect on organisational development.

Table 5. Regression results

$$
\left(R=0.626 ; R^{2}=0.392 ; \text { Adjusted } R^{2}=0.389 ; F \text { Stat }=67.238\right)
$$

\begin{tabular}{|l|c|c|c|c|c|}
\hline \multirow{2}{*}{ Model } & \multicolumn{2}{|c|}{ Unstandardised Coefficients } & $\begin{array}{c}\text { Standardised } \\
\text { Coefficients }\end{array}$ & \multirow{2}{*}{$\boldsymbol{T}$} & \multirow{2}{*}{ Sig. } \\
\cline { 2 - 5 } & $\boldsymbol{B}$ & Std. Error & Beta & & \\
\hline Constant & 3.668 & 0.395 & & 9.274 & 0.000 \\
\hline Job Rotation & 0.545 & 0.041 & 0.626 & 13.375 & 0.000 \\
\hline
\end{tabular}

Dependent Variable: Organisational Effectiveness

\section{Interpretation}

The result of the third hypothesis has $0.626(62.6 \%)$ as a value for beta coefficient, which reveals that job rotation has an effect on organisational development. $R^{2}$ value of $0.392(39.2 \%)$ indicates that job rotation accounts for $39.2 \%$ of variation in organisational development. $P<0.05$ signifies that the result is significant. The result of the hypothesis reveals that job rotation has a significant effect on organisational development. 


\section{DISCUSSION AND CONCLUSION}

The study examined the effect of skill mapping and talent pool management vis-a-vis organisational development. The results of the study were in line with various previous studies like those of (Sheokand and Verna, 2015; Gilbert, 2012; Kaur \& Kumar 2013; Krishnaveni, 2013 and Maura 2011). For example, Sheokand and Verna (2015) argued that although the study of skill mapping was debatable, for any organisation to develop, managers should keenly pay attention to skill mapping and management of talents, because it would enable them to appropriately allocate employees to tasks, and this definitely would lead to a high performing organisation. Kaur and Kumar (2013) found that employees should be supported and made to understand career development efforts required for the tasks to be given to them and the end result expected of them. The finding revealed that all the three variables that represented skill mapping and talent pool management (employee engagement, succession planning and job rotation) played a significant role in the development and performance of the entire system at large. It is worth noting that both organisations and employees benefit from skill mapping and talent pool management. The business benefits in terms of increased productivity, increased turnover, and commitment from dedicated employees, a good connection between business goals and individual's efforts. Equally, the employee's benefits are career development, increased knowledge, self-confidence, and job satisfaction.

\section{Recommendations}

The findings and conclusions from the study provide the basis for the following recommendations:

i. Organisations should maximise the utilisation of talents and competences by organising seminars and training that will teach employees the importance of skill deployment in order to acquire competitive edge.

ii. In other to stand tall in a changing business environment, organisations should obtain skill-based human resource management practices, which are necessary for productivity and performance of excellence.

iii. Managers should ensure that a competent employee is designated to a task, and to make sure that employees are fine with the training and facilities provided. Any narrative outside of this could lead to frustrations of employees at the organisation, which in the long run can lead to ineffectiveness.

iv. The organisation needs to set more specific goals in order to improve the achievement orientation of the employees. Irrespective of how skilful and properly allocated work to employees is, reasonable results may be unattainable at the end of the day, because goals and objectives are not clearly defined to those that will achieve them. 


\section{REFERENCES}

Aradhna, Y. (2017). Competency mapping for effective growth in retails, Journal of Business Theory and Practice, 5(1), 1-8. https://doi.org/10.22158/jbtp.v5n1p1

Bakker, R. T., \& Xu, H. I. (2011). Employee engagement: A literature review. International Journal of Human Resource Studies, 9(1), 63-80. https://doi.org/10.2478/ijme-2018-0018

Celia, B. R., \& Karthick, M. (2010). Employee development through competency mapping: A way ahead for organizational growth. International Journal in Management and Social Science, 4(6), 260-270.

Chandan, M. (2015). Need for competency mapping scale to map the competencies of university teaching personnel, Journal of Management Research and Analysis, 2(4), 273-276. https://doi.org/10.5958/23942770.2015.00005.8

Deepti, S., Sachin, S., \& Kalpana, S. (2017). Applying competency mapping in information technology sector. Journal of Business and Management, 3(7), 23-34.

Dehkordy, H. I. (2014). Study of factors affecting on talent management among Bank's employees in Shahrekord. International Journal of Scientific Research, 8(2), 1-10.

Draganidis, O., \& Mentzas. A. (2006). Competency based management; a review of systems and approaches. Information Management \& Computer Security, 14(1), 51-64. https://doi.org/10.1108/09685220610648373

Dunford, B. B. Snell, S. A., \& Wright, P. M. (2001). Human Resources and the Resource Based View of the Firm, CAHRS Working Paper 01-03, 2001.

Gallardo, G. A. (2013). Talent measurement: A holistic model and routes forward. Journal of Human Resource Management, 23(5), 290-300. https://doi.org/10.4102/sajhrm.v16i0.990

Garavan, T. N., Carbery, N., \& Rock, A. (2011). Mapping talent development: definition, scope and architecture. European Journal of Training and Development, 36(1), 6-18. https://doi.org/10.1108/03090591211192601

Genty, K. I. (2019). Training transfer: a moderator of entrepreneurial performance determinants. Economics and Business, 33(1), 69-81. https://doi.org/10.2478/eb-2019-0005

Gilbert, T. F. (2012). Human Competence, Silver Spring, MD: International Society for Performance Improvement. Journal of Human Resource Management, 34(9), 167-170.

Jayaraman, S. Parvaiz, T., \& Ahmad, F. (2018). Integrated talent management scale: Construction and initial validation. SAGE Open, 44(1), 1-12. https://doi.org/10.1177/2158244018780965

Kaur, J., \& Kumar, V. (2013). Examining the impact of competency mapping in, organization. International Journal of Education and Research, 1(1), 15-21.

Krishnaveni, J. (2013). A study on mapping of employee's competency. Indian Journal of Economics and Development, 1(3), 71-75.

Masri, N. E., \& Suliman, A. (2019). Talent management, employee recognition and performance in the research institutions, Journal of Economics and Business, 14(1), 127-140. https://doi.org/10.2478/sbe-2019-0010

Mattone, J., \& Xavier, L. (2013). Talent Leadership: A Proven Method for Identifying and Developing HighPotential Employees, AMACOM.

Maura, S. (2011). Mapping talent development: definition, scope and architecture, European Journal of Training and Development, 36(1), 6-18.

Mensah, J. K. Bawole, J. N., \& Wedchayanon, N. (2016). Unlocking the "black box" in the talent management employee performance: relationship: evidence from Ghana. Journal of Management Research Review, 39(12), 1546-1566. https://doi.org/10.1108/MRR-08-2015-0190

Mensah, J. K. (2015). A "coalesced framework" of talent management and employee performance: For further research and practice. International Journal of Productivity and Performance Management, 64(4), 544566. https://doi.org/10.1108/IJPPM-07-2014-0100

Nair, P. J. (2012). Is talent management accentuated by competency mapping?: With Special Reference to Educational Sector. International Journal of Social Sciences \& Interdisciplinary Research, 1(11), 132-147.

Oladapo, V. (2014). The impact of talent management on retention. Journal of Business Studies Quarterly, 5(3), 19-36.

Seniwoliba, A. J. (2015). Succession planning: Preparing the next generation workforce for the University for Development Studies. Research Journal of Educational Studies and Review, 1(1), 2-10.

Sheokand, S., \& Verma. A. (2015). Talent Management: A Birde's Eye View. International Research Journal of Social Sciences, 4(2), 52-58.

Smithesh, G., \& Shameem, A. (2018). A study on competency mapping and its impact on deliverables with respect to the reality sector. International Journal of Civil Engineering and Technology, 9(1), 179-190.

Soundara, R., \& Ananda, K. (2016). Competency Mapping Analysis: A Study Conducted in Specific Package Industry at Puducherry State of India. European Journal of Business and Management, 7(19), 147-157. 
Sparrow, P. R., \& Makram, H. (2015). What is the value of talent management? Building value-driven processes within a talent management architecture. Human Resource Management Review, 25(3), 249-263. https://doi.org/10.1016/j.hrmr.2015.04.002

Tatoglu, E. Glaister, A.J., \& Demirbag, M. (2016). Talent management motives and practices in an emerging market: A comparison between MNEs and local firms. Journal of World Business, 51(2), 278-293. https://doi.org/10.1016/j.jwb.2015.11.001

Tetik, S. (2016). Talent management: A review of theoretical perspectives and a guideline for practitioner. Nile Journal of Business and Economics, 4(1), 40-56. https://doi.org/10.20321/nilejbe.v2i4.77

Thomas, N. G., Carbery, R., \& Rock, A. (2011). Mapping talent development: Definition, scope and architecture, European Journal of Training and Development, 36(1), 5-24, Emerald Group Publishing Limited. https://doi.org/10.1108/03090591211192601

Yamane, T. (1967). Statistics, an introductory analysis, 2nd ed. New York: Harper and Row.

\section{AUTHORS' SHORT BIOGRAPHIES}

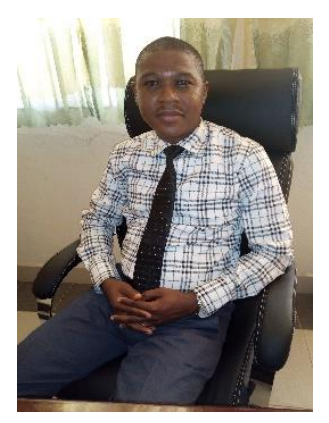

Dr Matthew Adekunle ABIORO is a Lecturer at the Department of Business Administration, Federal University of Agriculture, Abeokuta, Nigeria. He received his B.Sc. in Accounting from Olabisi Onabanjo University, Ago-Iwoye, Nigeria, M. Sc.in Management from the University of Lagos, Nigeria and was awarded the degree of Doctor of Philosophy (Ph. D.) in Management Science specialising in Human Resource Management from Ladoke Akintola University of Technology, Ogbomoso, Nigeria, in 2016. Dr Matthew Abioro is an Associate Member of the Chartered Institute of Personnel Management (CIPM) and a Member of Nigerian Institute of Management (NIM). Dr Abioro's area of specialisation includes human resource management, organisational behaviour, industrial relations and strategic management. He is passionate about teaching and mentoring and has made multiple pedagogical presentations on management consulting, teaching enhancements and has had papers published in both local and internationals journal outlet.

E-mail: abioroma@funaab.edu.ng

ORCID iD: https://orcid.org/0000-0003-2185-1085

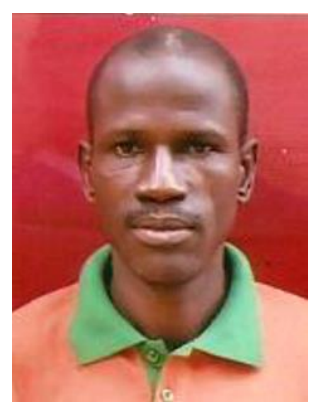

Dr Olabisi Jayeola is a Senior Lecturer at the Department of Accounting, Federal University of Agriculture, Abeokuta, Nigeria. He received his B. Sc., M. Sc., M. Phil., and Ph. D. in Management Accounting from Obafemi Awolowo University, Osun State; University of Lagos and Babcock University, Ogun State, Nigeria, in 2014. Dr Olabisi Jayeola is a Fellow of the Institute of Chartered Accountants of Nigeria (ICAN); Associate Member of Chartered Institute of Taxation of Nigeria; Associate Member of the Nigerian Institute of Management; Associate Member of the Institute of Cost and Management Accountants. His lecturing experience is over fifteen years at different levels within different universities in Nigeria. He has occupied different academic positions within the universities in Nigeria such as Departmental Examination Officer, Head of the Department of Accounting, Deputy Dean of the College and Acting Dean of the College. Dr Olabisi's area of specialisation is management accounting, and he is experienced in theoretical and practical aspects of accounting. Currently, he is teaching Financial Accounting, Management Accounting, Oil \& Gas Accounting and Research Methodology to both undergraduate and postgraduate students.

E-mail: olabisij@ funaab.edu.ng

ORCID iD: https://orcid.org/0000-0002-5390-0307

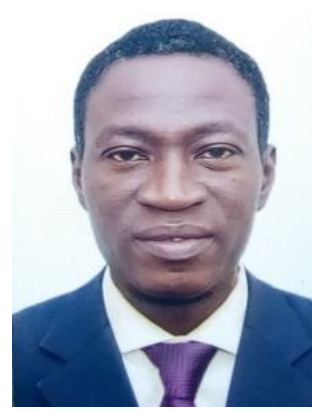

Dr Isaac Oladapo ONIGBINDE is an Associate Professor at the Department of Business Administration at McPherson University, Nigeria. He obtained his (Ph. D.) degree in Marketing from Babcock University, Ogun State, Nigeria, in 2013. Dr Onigbinde is a Fellow of the Institute of Management Consultant and a Full Member of the National Institute of Marketing of Nigeria. He specialises in digital marketing, entrepreneurial marketing, marketing analysis and consumer behaviour.

E-mail: ionigbinde@mcu.edu.ng 


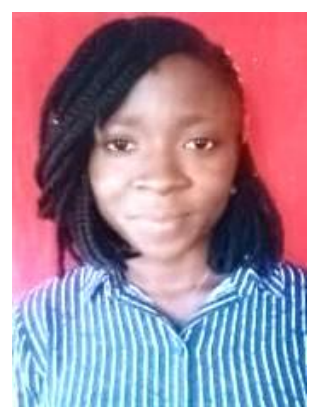

Adedolapo Mercy ADEDEJI is an aspiring specialist in human resource management who obtained her undergraduate degree in Business Administration from the Federal University of Agriculture, Abeokuta, Nigeria, in 2020. She is a Member of the Institute of Strategic Management (ISMN) and Nigerian Institute of Management (NIM). Adedolapo Adedeji's research interests include corporate planning, human resource management, entrepreneurship and comparative management.

E-mail: amazingroyalty@gmail.com 